\title{
Hidden crown jewels: the role of tree crowns for bryophyte and lichen species richness in sycamore maple wooded pastures
}

\author{
Thomas Kiebacher $^{1} \cdot$ Christine Keller $^{1} \cdot$ Christoph Scheidegger $^{1} \cdot$ \\ Ariel Bergamini ${ }^{1}$
}

Received: 18 December 2015/Revised: 11 May 2016/Accepted: 18 May 2016/

Published online: 27 May 2016

(C) Springer Science+Business Media Dordrecht 2016

\begin{abstract}
Tree crowns typically cover the vast majority of the surface area of trees, but they are rarely considered in diversity surveys of epiphytic bryophytes and lichens, especially in temperate Europe. Usually only stems are sampled. We assessed the number of bryophyte and lichen species on stems and in crowns of 80 solitary sycamore maple trees (Acer pseudoplatanus) at six sites in wooded pastures in the northern Alps. The total number of species detected per tree ranged from 13 to 60 for bryophytes, from 25 to 67 for lichens, and from 42 to 104 for bryophytes and lichens considered together. At the tree level, $29 \%$ of bryophyte and $61 \%$ of lichen species were recorded only in the crown. Considering all sampled trees together, only $4 \%$ of bryophyte, compared to $34 \%$ of lichen species, were never recorded on the stem. Five out of 10 red-listed bryophyte species and 29 out of 39 red-listed lichen species were more frequent in crowns. The species richness detected per tree was unexpectedly high, whereas the proportion of exclusive crown species was similar to studies from forest trees. For bryophytes, in contrast to lichens, sampling several stems can give a good estimation of the species present at a site. However, frequency estimates may be highly biased for lichens and bryophytes if crowns are not considered. Our study demonstrates that tree crowns need to be considered in research on these taxa, especially in biodiversity surveys and in conservation tasks involving lichens and to a lesser degree also bryophytes.
\end{abstract}

Keywords Acer pseudoplatanus · Alps · Biodiversity · Epiphytes · Red-listed species · Tayloria rudolphiana

Communicated by Pradeep Kumar Divakar.

Electronic supplementary material The online version of this article (doi:10.1007/s10531-016-1144-4) contains supplementary material, which is available to authorized users.

Thomas Kiebacher

thomas.kiebacher@wsl.ch

1 Swiss Federal Institute for Forest, Snow and Landscape Research WSL, Zürcherstrasse 111, 8903 Birmensdorf, Switzerland 


\section{Introduction}

Trees are very important habitats for epiphytic bryophytes and lichens. Species richness on single trees can be extremely high, especially in the tropics where up to 110 bryophyte (Romanski et al. 2011) or 173 lichen (Aptroot 1997) species on a single tree may be found. Epiphytic bryophytes and lichens are a diverse group of species in temperate areas as well (see Barkman 1958), and they contribute strongly to the species richness of regions with many specialist species confined to trees, such as many Orthotrichum or Usnea species.

The assessment of the diversity of epiphytic bryophytes and lichens faces several problems: trees have a complex three-dimensional architecture that is difficult to access, and microclimatic conditions vary greatly within a tree depending on the exact position (e.g. stem, inner crown, outer crown) and the surrounding vegetation (Barkman 1958; Barker and Pinard 2001), making it extremely laborious to sample all microhabitats.

A frequently used sampling method in diversity assessments of epiphytic bryophytes and lichens is to survey only the stems of individual trees. Stems are sampled either by using predefined plots (e.g. Rasmussen 1975; Scheidegger et al. 2002a; Lõhmus et al. 2006; Jüriado et al. 2009; Paltto et al. 2011) or by studying the whole stem up to a certain height (often 2 m; e.g. Friedel et al. 2006; Lie et al. 2009; Buckley 2011; Caruso et al. 2015; Whitelaw and Burton 2015). Tree crowns, which comprise the vast majority of the surface area of trees (Sillett and Antoine 2004), are rarely considered, especially in temperate Europe (Sillett and Antoine 2004; Boch et al. 2013a).

Tree crowns often host a considerable number of species that are overlooked when only the stems are sampled (Fritz 2009; Boch et al. 2013a; Marmor et al. 2013). Furthermore, surveying only the lower part of the stem can underestimate the number of red-listed species (Fritz 2009). Ignoring the crown might thus lead to biased species richness and frequency estimations of crown specialists. So far tree crowns have been investigated in forests (e.g. Hale 1952; Fritz 2009; Boch et al. 2013a; Marmor et al. 2013) but not on solitary trees which are exposed to different environmental conditions (Barkman 1958), and may thus be very different from forest trees with respect to the importance of the crown for the occurrence of epiphytic species.

Epiphytic species on trees exhibit distinct patterns of vertical distribution (Hale 1952, 1965; Yarranton 1972; Kenkel and Bradfield 1986; Coote et al. 2008). From the base of a forest tree to its crown, light intensity, wind and evaporation increase considerably, while temperature variations are largest at the base of the trunk and at the top of the crown (Barkman 1958). Environmental conditions in crowns of solitary trees are very similar to those of forest trees, but conditions at the base of solitary trees are quite different, with high maximum temperatures and severe drought (Barkman 1958). Old trees, either in forests or growing solitarily, are important for the conservation of epiphytic bryophytes and lichens, and they are a key habitat for many red-listed species (Wirth 1987; Rose 1991; Vanderpoorten et al. 2004; Ranius et al. 2008; Fritz et al. 2009a).

Here, we focus on sycamore maple (Acer pseudoplatanus) in wooded pastures, a traditional land management system in the montane region of the northern Alps. These pastures represent a parkland-like landscape timbered with scattered sycamore maple trees (Figs. S1 and S2 in Online Resource 1). Many of these trees are old and densely covered with bryophytes and lichens. Despite their obvious abundance in epiphytic lichen and bryophyte biomass, the diversity of epiphytic species on these trees has never been thoroughly studied. In particular, we are not aware of any study where the trees were climbed in order to assess the species in the crowns. 
The objectives of this study were to (i) measure the overall diversity of bryophytes and lichens on trees in temperate climates, (ii) examine which portion of these species is overlooked if only stems are sampled, (iii) asses the relationship between the diversity on the stem and the additional diversity in the crown and (iv) evaluate the importance of tree crowns as a habitat for red-listed species.

\section{Methods}

\section{Study sites}

The study sites are located in the northern Alps where typical sycamore maple wooded pastures occur. Six sites were selected along the east-west axis of the Alps (Fig. 1; Table S1 in Online Resource 1). Each site is comprised of one valley with abundant sycamore maple wooded pastures. All sites are part of the Atlantic climate region and are characterized by a temperate mountain climate, with precipitation ranging from 956 to

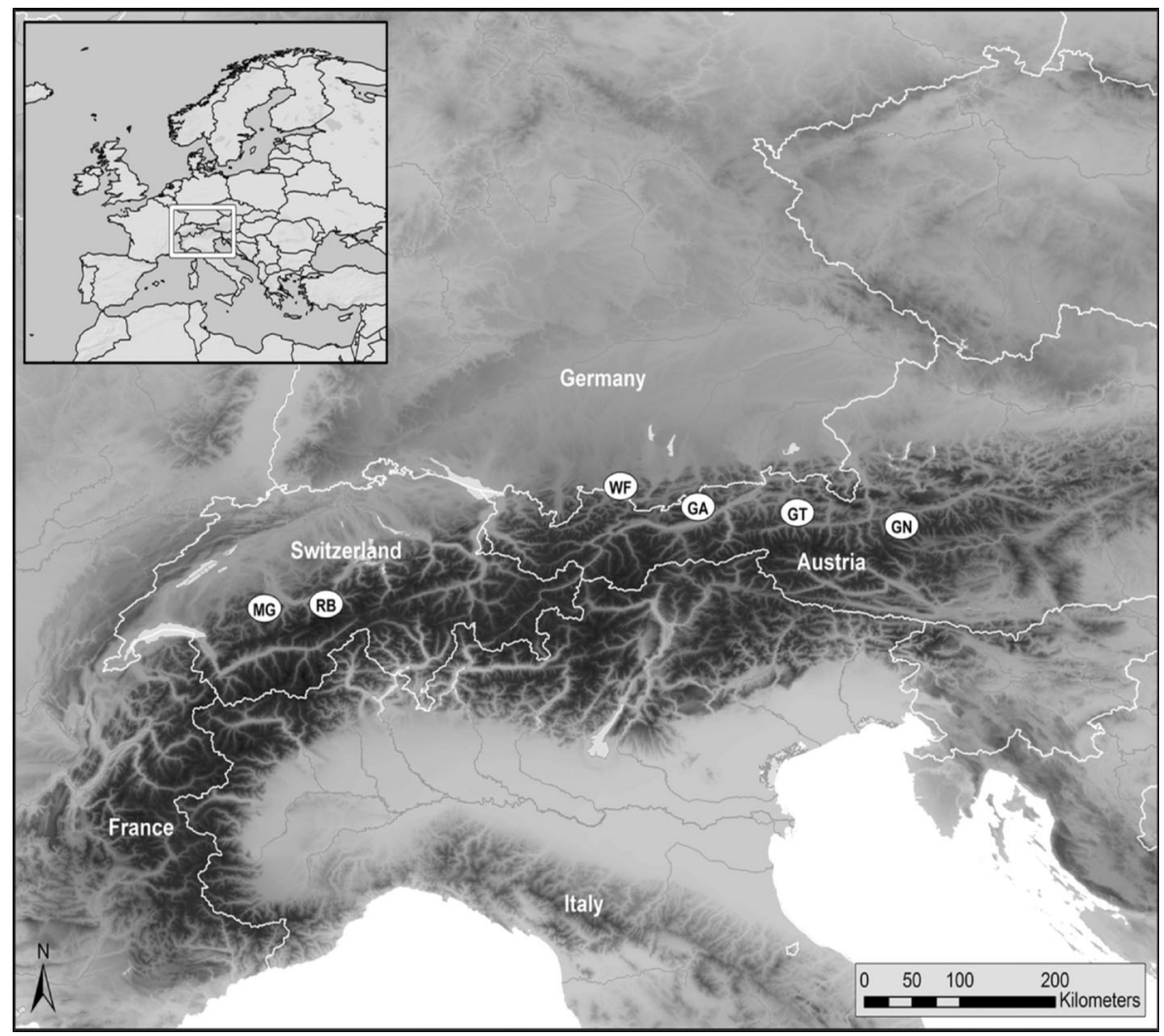

Fig. 1 Location of the six study sites in the northern Alps. RB Reichenbachtal (Bern, CHE), MG Meniggrund (Bern, CHE), GA Grosser Ahornboden (Tyrol, AUT), WF Wanker Fleck (Bavaria, DEU), GN Gnadenalm (Salzburg, AUT), GT Glemmtal (Salzburg, AUT). USGS EROS Data Center; ESRI: ArcWorld Supplement and Data Solutions, B.V 
$1563 \mathrm{~mm}$ per year (Baumgartner et al. 1983; see Table S1 in Online Resource 1). Three of the sites, Reichenbachtal (RB), Grosser Ahornboden (GA) and Gnadenalm (GN), were chosen because the rare and threatened bryophyte species Tayloria rudolphiana was recently recorded there.

\section{Tree selection}

For the selection of trees, all sycamore maple wooded pastures within each valley, starting from an elevation of $1000 \mathrm{~m}$ a.s.l. up to the upper limit of their occurrence at ca. $1700 \mathrm{~m}$ a.s.l., were considered. In each valley, the sycamore maple trees in the pastures were digitized using recent (2009-2012) colour infrared images. Sycamore maple trees are easily distinguished from coniferous trees on these images but not from other deciduous trees. However, other deciduous trees were rare at the studied sites. The Wanker Fleck (WF) site was an exception, and a considerable number of beech trees were present there. To select trees for field sampling, we applied a stratified random sampling procedure to the digitized trees in order to capture the ecological variability of each site. Three factors were used for the stratification: annual global potential shortwave radiation (sradyy; algorithm following Kumar et al. (1997)), distance to the next river, and number of neighbouring trees. We defined two levels within each of the three stratification factors, leading to a total of 8 different factor combinations $(2 \times 2 \times 2)$. Each of the digitized trees was assigned to one of these factor combinations. For the radiation factor, we set a threshold value reflecting radiation at a flat point approximately in the centre of each site but avoiding parts where the surrounding mountains exhibited a considerable impact on the value. This threshold value ranged between 14,700 and $16,700 \mathrm{~kJ} \mathrm{~m}^{-1}$ day $^{-1}$. Radiation generally has a positive effect on the diversity of epiphytic bryophytes and lichens (Löbel et al. 2006; Buckley 2011) and also has a strong effect on air humidity (Yang and Koike 2002). The factor "distance to the next river" was chosen to account for different levels of air humidity. Sites close to rivers are characterized by high air humidity (e.g. Stewart and Mallik 2006), which promotes the diversity of epiphytic bryophytes and lichens (Heylen et al. 2005; Hylander et al. 2005). We choose a threshold value of $50 \mathrm{~m}$ distance to the next river to group the trees into two classes. The factor "number of neighbouring trees" was used to account for different levels of connectivity, a crucial factor for the diversity of epiphytic bryophytes and lichens (e.g. Sillett et al. 1995; Löbel et al. 2009; Johansson et al. 2012). When the distance between the centres of the crowns of two neighbouring trees was less than $20 \mathrm{~m}$, the trees were considered part of the same stand. We grouped the stands into small $(<4$ trees) and large stands (four or more trees). Since we aimed at a representative selection of trees per site we sampled only one tree per selected stand.

We then randomly selected two trees from each factor combination, leading to a total of 16 trees per site. However, at GA, WF, GN and Glemmtal (GT), only 12 trees were selected because not all factor combinations were present. In total, 80 trees were examined. Only trees with a minimum diameter at breast height ( $\mathrm{DBH}$; sampled at $1.3 \mathrm{~m}$ height) of $36 \mathrm{~cm}$ were considered. Trees that did not comply with the stipulated specifications (not a sycamore maple or $\mathrm{DBH}<36 \mathrm{~cm}$ ) were replaced by the nearest tree of the same factor combination. In the field, we measured the $\mathrm{DBH}$, the total height and the height of the lowest big branch of each sampled tree. Tree size and DBH is frequently not closely related to tree age (Boudreault et al. 2000; Dittrich et al. 2013). Therefore, we used other proxies based on their phenology ("phenological age") to classify the trees into young and mature trees. Trees with smooth stem bark and with a regular branching pattern were defined as young trees, and trees with cracked bark and an irregular branching pattern (caused by the 
loss of some of the branches) were defined as mature trees. Most of the tree crowns were distinctly higher than wide and we thus approximated the crown volume as the height of the crown (total height-height of the lowest big branch) $\times$ projected crown area (derived from orthophotos). The DBH of the sampled trees varied between 36.3 and $167.8 \mathrm{~cm}$ $(77.4 \pm 29.5$, mean $\pm \mathrm{SD}$ ), their height ranged from 8.9 to $25.0 \mathrm{~m}(16.8 \pm 3.9)$ and the volume of the crown ranged from 122 to $6044 \mathrm{~m}^{3}$ (1622 \pm 1189$)$.

\section{Sampling}

Field work was carried out between April and September of 2012 and 2013. On each tree, a total of 13 plots were sampled. Two plots were located on the stem and 11 in the crown. The locations of the two stem plots were predefined: the first plot included the whole circumference of the stem from the ground up to $0.5 \mathrm{~m}$, including major roots if they were above the soil surface. The top of the second plot was located at the base of the lowest big branch and the plot extended $0.75 \mathrm{~m}$ downwards along the stem, again including the whole circumference of the stem. The two plots did not overlap on any sampled tree. On average, the lowest big branch was at a height of $2.6 \mathrm{~m}( \pm 1.2 \mathrm{SD})$. Frequently, the lower part of the trunk (around $1 \mathrm{~m}$ height) was affected by mechanical disturbance from cattle, which led to almost bare bark and only a few bryophytes and lichens. In most cases, all species present on the stem were included in these two plots. The plots in the crown were semiselectively placed in four different microhabitats: two rectangular plots were placed in the major crutches of the tree. The size of these plots varied according to the anatomy of the crutch. Three plots were placed on the largest branches available (including the stem within the crown), three on branches with an intermediate thickness, and three on thin branches in the outer crown. The length of all branch plots was $0.6 \mathrm{~m}$ and for each plot the whole circumference of the branch was examined. The diameter of the largest branches ranged from 9.5 to $73.2 \mathrm{~cm}(26.6 \pm 10.8$, mean $\pm \mathrm{SD})$, that of intermediate branches ranged from 3.8 to $19.1 \mathrm{~cm}(8.3 \pm 2.6)$, and that of the thin branches ranged from 1.4 to $4.1 \mathrm{~cm}(2.7 \pm 0.5)$. To assess these latter plots, thin branches were cut using a $6 \mathrm{~m}$ long telescopic tree pruner. To assess the other plots, which were inaccessible from the ground, tree climbing techniques were applied. Within each plot, the presence of all bryophyte species was recorded. Bryophyte species that could not be identified in the field, as well as all lichen species, were collected and examined in the lab. The main focus of the study was on the diversity of bryophytes, with the objective of maximizing the number of bryophyte species recorded for each tree. The sampling strategy was as follows: first, the two stem plots were surveyed. Then, the tree was climbed and plots were placed in the four microhabitats in the crown so that additional bryophyte species were represented in the plots. If no additional bryophyte species could be found in one of the crown microhabitats, we tried to cover the structural and ecological variability of the corresponding microhabitat with the remaining plots. Dead parts of the tree were excluded from sampling.

By applying this sampling method, we aimed to obtain a list of bryophyte species per tree that was as complete as possible. Preliminary tests and field observations showed that we most likely formed a nearly complete list of bryophyte species per tree. Because we focused on the bryophytes to locate the plots in the tree crown, lichens were most likely not as completely sampled as bryophytes. However, since the two stem plots were chosen at predefined places, i.e. without any preference for species occurrences, lichen and bryophyte species richness on the stems allows an unbiased comparison of the diversity of the two groups. Moreover, we estimated how many additional species were found in the crown. For lichens, this probably represents a lower bound estimate. 


\section{Nomenclature and definition of species groups}

The nomenclature for bryophytes followed Hill et al. (2006) and Söderström et al. (2002, 2007). The nomenclature for lichens followed Clerc and Truong (2012) and, for species not included in that publication, Wirth et al. (2013) and Saag et al. (2009). Species belonging to taxonomically difficult species groups were treated as aggregates (see Table S2 in Online Resource 1).

Species were classified into two groups: epiphytes, i.e. species that preferably grow on the bark of living trees or shrubs in the study area, and non-epiphytes which in fact are facultative epiphytes that usually prefer other substrates. Classifications were based on Clauzade et al. (1985), Frahm and Frey (1992), Nebel and Philippi (2000, 2001, 2005), Ignatova and Ignatov (2011) and Wirth et al. (2013) and on our field experience from the study region.

Red-listed species were defined as species with a Red List status of critically endangered (CR), endangered (EN) or vulnerable (VU) (IUCN 2001) according to Schnyder et al. (2004) for bryophytes and Scheidegger et al. (2002b) for lichens. Species which are not listed in these publications remained unclassified and were not treated as red-listed species. We chose to use only the Swiss Red Lists because they were the only ones available that both applied the new IUCN criteria (IUCN 2001). Furthermore, the Alps make up a large part of Switzerland's area. Switzerland's bryophyte and lichen flora is thus expected to be representative for the study region.

\section{Analyses}

Data were analysed using R, version 3.1.3 (R Core Team 2015). The analyses were performed with two datasets: the full dataset including all species and a reduced dataset including only the epiphytes. To test the efficiency of the sampling design and to estimate the extent to which it covered the total species richness of the two groups, we calculated species accumulation curves. For each tree, we calculated 50 accumulation curves by randomly adding the 11 crown plots to the two stem plots. To evaluate how completely we sampled lichen and bryophyte species richness, we calculated then mean accumulation curves.

The proportion of species recorded on the stems and only in the crowns were analysed at the tree level, the site level and the regional level (all 80 trees from all sites). To calculate species richness at the site level, we merged the records from the 12 trees per site. For RB and Meniggrund (MG), sites where we examined 16 trees, we took the mean value of 50 random selections of 12 trees without replacement. We further calculated species accumulation curves by randomly adding trees considering all plots on the trees, the stem plots only and the crown plots only. For each accumulation curve, we used 200 random permutations of the trees. The comparison of these accumulation curves between bryophytes and lichens and between all species and epiphytes provided an indication of the importance of sampling the crown to obtain a reasonable estimate of the species richness of these groups on the trees. To test for differences in the number of bryophyte and lichen species on the stem we used a paired-sample $t$ test (two-tailed).

To analyse the relationship between the number of species recorded only in the crowns and the number of species on the stems, we applied linear mixed effects models (LMER, Bates et al. 2015) with study site as a random intercept factor. The number of species on the stem and a set of tree parameters and environmental variables were considered as fixed 
factors. As tree parameters we chose $\mathrm{DBH}, \log$-transformed volume of the crown, and phenological age. As environmental variables we chose altitude a.s.l., mean annual precipitation, sradyy and log-transformed distance to the next river. All predictors, except phenological age, were continuous. Mean annual precipitation was derived from a $100 \mathrm{~m}$ grid interpolated with the algorithm following Zimmermann and Roberts (2001) from the 1950-2000 means of the WorldClim data (Hijmans et al. 2005). For the sampled trees, altitude a.s.l. ranged from 1048 to $1529 \mathrm{~m}$, mean annual precipitation from 965 to $1563 \mathrm{~mm}$, sradyy from 9964 to $22,360 \mathrm{~kJ} \mathrm{~m}^{-2}$ day $^{-1}$ and distance to the next river from 2 to $3330 \mathrm{~m}$.

We tested for collinearities between all predictors and found that altitude and mean annual precipitation were highly correlated (Spearman's rho $>0.7$ ). We chose to exclude mean annual precipitation from the analyses because we had precise measurements of altitude but only extrapolated values for precipitation. Although our field experience and the selection of the plots allowed us to sample a nearly complete bryophyte species list per tree, we are aware that the lichen species list might have remained incomplete. Therefore, for lichens we also included the log-transformed area sampled in the crown as a fixed factor in the model. Furthermore we included all two-way interactions between the number of species on the stem and each of the other predictors in the models. After fitting these initial models, we applied the 'step' function of the 'lmerTest' package in R (Kuznetsova et al. 2015). This function performs automatic backward elimination of non-significant effects (we retained the random factor site and used $p \geq 0.05$ for fixed factors). The $p$ values were calculated from $F$ statistics based on Sattethwaite's approximation of degrees of freedom (Kuznetsova et al. 2015). The final models were evaluated with $t$ statistics based equally on Sattethwaite's approximation for denominator degrees of freedom for the fixed factors and with likelihood ratio test $\mathrm{CHI}^{2}$ statistics for the random factor site (Kuznetsova et al. 2015). Visual inspection of residual plots did not reveal any obvious deviation from homoscedasticity or normality and Cook's distances revealed no outliers.

The crown preference of species (i.e. whether the species was more frequent in crowns) was calculated as the number of trees where the species was recorded in the crown divided by the total number of trees where the species was found. The significance of this proportion was tested with Fisher's exact test.

\section{Results}

\section{Total number of species}

In total we recorded 388 species, including 161 bryophytes and 227 lichens. Forty bryophyte species and 199 lichen species were epiphytes. Ten bryophyte species (7 were epiphytes) and 39 lichen species (all were epiphytes) were red-listed species (see complete species list in Table S3 in Online Resource 1).

The number of bryophyte species per tree ranged from 13 to 60 (28.2 \pm 8.7 , mean $\pm \mathrm{SD})$ and that of epiphytes ranged from 9 to $26(16.3 \pm 3.2)$. The number of lichen species per tree ranged from 25 to $67(43.9 \pm 7.3)$ and that of epiphytes ranged from 24 to 63 (34.0 \pm 6.9 ; Fig. 2). Considering bryophytes and lichens together, the number of species per tree ranged from 42 to $104(72.0 \pm 10.8)$. 

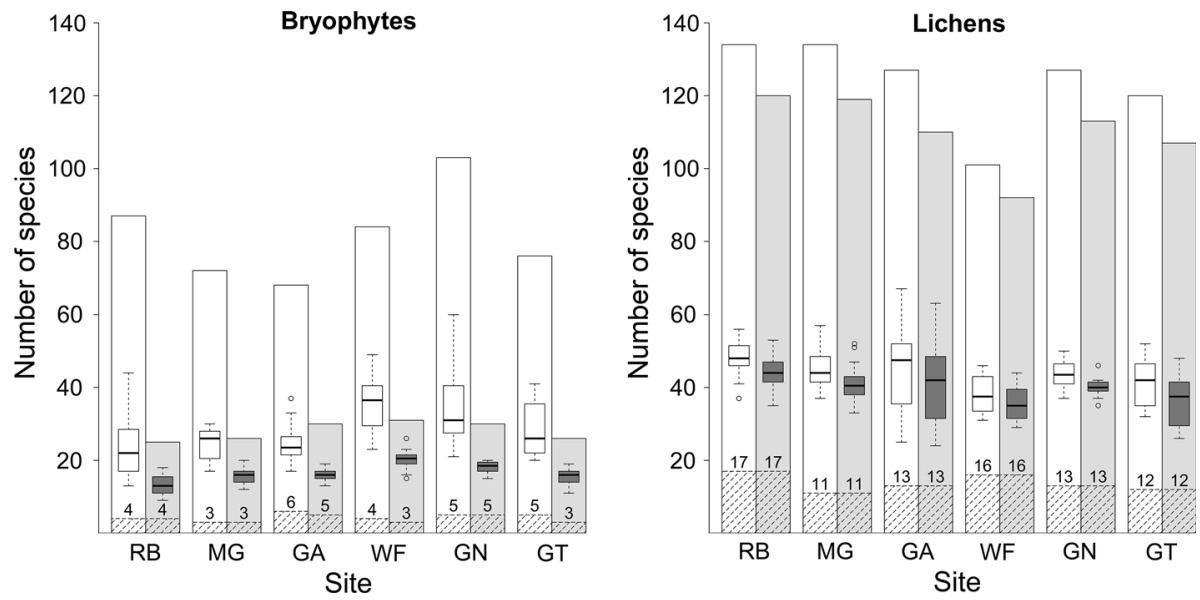

Fig. 2 Bryophyte and lichen species richness per site and tree. Bars indicate species numbers per site while boxplots indicate species numbers per tree within sites. White: all species, grey: only epiphytes; dashed bars with numbers: number of red-listed species. RB Reichenbachtal (Bern, CHE), MG Meniggrund (Bern, CHE), GA Grosser Ahornboden (Tyrol, AUT), WF Wanker Fleck (Bavaria, DEU), GN Gnadenalm (Salzburg, AUT), GT Glemmtal (Salzburg, AUT)

The number of red-listed bryophyte species per tree ranged from zero to four species per tree $(1.5 \pm 0.9$; for epiphytes: $1.4 \pm 0.9)$. The number of red-listed lichen species ranged from zero to seven species per tree ( $2.5 \pm 1.7$, all were epiphytes; Fig. 2).

The mean accumulation curves per tree were different for bryophytes and lichens. While the curves clearly flattened for bryophytes, indicating that bryophyte sampling was

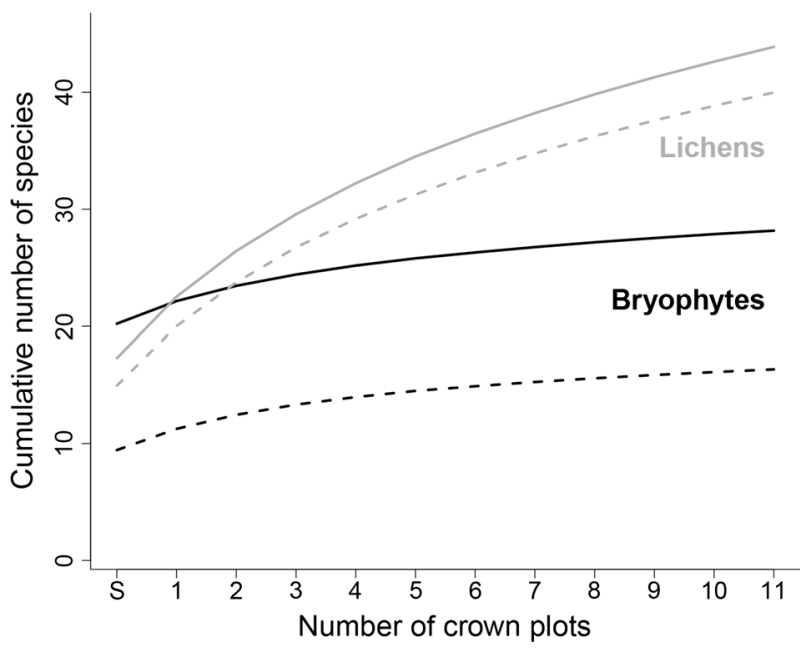

Fig. 3 Species accumulation curves for bryophytes and lichens in relation to the number of crown plots. The curves represent the mean of 80 curves (one for each tree). The curves for each tree were calculated as the mean of 50 accumulation curves, which were derived by randomly adding the 11 crown plots to the two stem plots. Solid lines: all species, dashed lines: only epiphytes; S: number of species on the stem 
close to complete, this was much less the case for lichens (Fig. 3). The addition of the 11th (=last) crown plot increased the number of bryophyte species by 0.30 (epiphytes by 0.23 ), whereas it increased the number of lichen species by 1.23 (epiphytes by 1.13).

Interestingly, the two stem plots combined included more bryophyte than lichen species $(p=0.031)$. However, when only epiphytes were considered, lichens had a higher species richness on the stems than bryophytes $(p<0.000)$. Thus, the contribution of non-epiphytes to the diversity on the trees was higher for bryophytes than for lichens. For both bryophytes and lichens, the proportion of epiphytes increased by adding crown plots to the two stem plots (Fig. 3).

\section{Additional diversity in the crown}

At the tree level, an average of 20.2 bryophyte and 17.3 lichen species were recorded on the stem compared to 28.2 and 43.9 species on the whole tree. The tree crown thus contributed a large number of species, more pronounced so for the lichens. The same was true when considering the epiphytes only (Fig. 4, see Table S4 in Online Resource 1 for numbers of epiphytes only). At the tree level, the bryophyte species recorded only in the crown accounted on average for $29.1 \%$ of the bryophyte diversity of the whole tree (Fig. 5; see Table S4 in Online Resource 1 for numbers of epiphytes only). For lichens, this percentage was much higher $(60.7 \%)$. At the site level, the difference between bryophytes and lichens was even more pronounced $(9.3$ vs. $42.4 \%)$ and at the regional scale where all 80 trees were considered together, only $3.7 \%$ of the bryophyte species but still $33.9 \%$ of the lichen species were never recorded on the stems. The cumulative species numbers in the different sections of the trees revealed considerable differences between bryophytes and lichens (Fig. S3 and S4 in Online Resource 1). For bryophytes, the number of species recorded only in crowns decreased with an increasing number of sampled trees. The continuous increase in the total species number was mainly caused by non-epiphytes

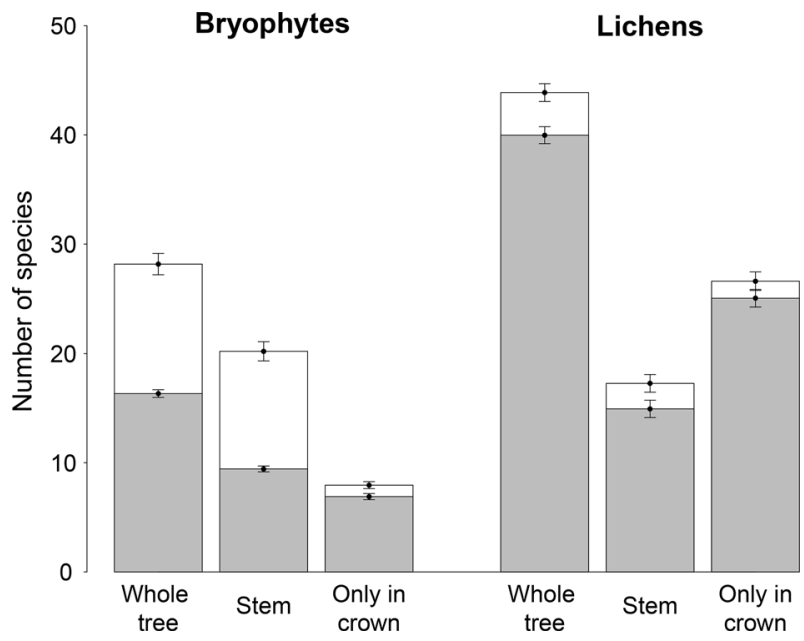

Fig. 4 The number (mean \pm SE) of bryophyte and lichen species found on the whole tree surface and on the stem, and the number of species recorded only in the crown. White all species, grey only epiphytes 


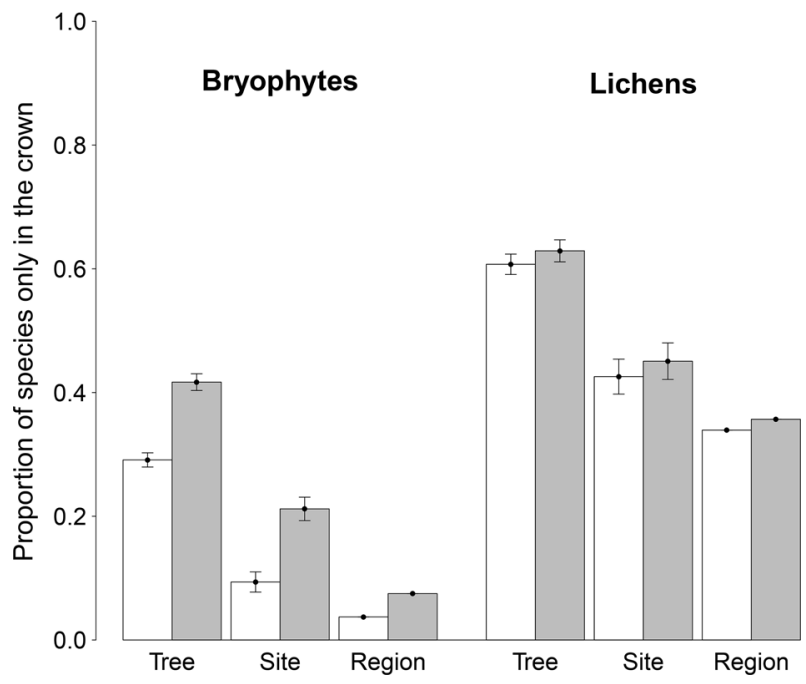

Fig. 5 Proportion (mean $\pm \mathrm{SE}$ ) of bryophyte and lichen species recorded only in tree crowns at three spatial levels: a tree, b site (12 trees), and c region (all 80 trees from all sites). White all species, grey only epiphytes

recorded on the stems. For lichens, the number of species recorded only in crowns increased with an increasing number of sampled trees. The continuous increase of the total species number was therefore mainly caused by epiphytes.

\section{Relationship between additional diversity in the crown and diversity on the stem}

Number of bryophyte species recorded only in the crown was negatively related to the species recorded on the stem and decreased by 0.24 species with each additional stem species (Table 1; Fig. S5 in Online Resource 1). Phenological age was the most important variable (highest $t$-value). The number of species recorded only in the crown was higher on phenologically old than on young trees and decreased at higher altitudes.

The number of lichen species recorded only in the crown decreased by 0.52 with an increase of one species recorded on the stem (Table 1; Fig. S5 in Online Resource 1). This effect was highly significant and was the most important of the three fixed factors retained in the final model. Furthermore, the number of species recorded only in the crown was negatively related to DBH but was higher on phenologically old trees compared to young trees.

\section{Crown preference and red-listed species}

Most bryophytes (98 out of 161 species) were recorded only on stems (Fig. 6). Thirty-one species were observed more often in crowns and 14 species were significantly more frequent in crowns than on the stems (Fisher's exact test, $p<0.05$ ). Five out of 10 redlisted species were more frequent in crowns, and this difference was significant for the two species Ulota coarctata and Orthotrichum rogeri. The threatened moss Tayloria rudolphiana was recorded six times in the crown and just once on the stem. 
Table 1 Results of the linear mixed effects model analyses for the number of bryophyte and lichen species recorded only in the tree crown. All fixed factors are continuous variables, except phenological age (twolevel factor, young vs. mature trees). Tests on the random factor site were performed with $\mathrm{CHI}^{2}$ statistics and corresponding $p$ values were derived by means of likelihood ratio tests. Fixed factors were tested with $t$ statistics based on Satterthwaite approximation for denominator degrees of freedom (df). ${ }^{\#} p<0.1,{ }^{*} p<$ $0.05, * * p<0.01, * * * p<0.001$

\begin{tabular}{|c|c|c|c|c|c|c|c|}
\hline \multicolumn{8}{|c|}{ Bryophyte species recorded only in the tree crown } \\
\hline Random factor & Variance & & $\mathrm{SD}$ & & $\mathrm{CHI} \mathrm{df}$ & $\mathrm{CHI}^{2}$ & $p$ \\
\hline Site & 0.783 & & 0.885 & & 1 & 3.833 & $0.050^{\#}$ \\
\hline Residual & 3.926 & & 1.981 & & & & \\
\hline \multicolumn{2}{|l|}{ Fixed factors } & \multicolumn{2}{|l|}{ Estimate } & SE & df & $t$ & $p$ \\
\hline \multicolumn{2}{|l|}{ Intercept } & \multicolumn{2}{|l|}{15.600} & 3.719 & 47.1 & 4.194 & $0.000^{* * *}$ \\
\hline \multicolumn{2}{|c|}{ No. species on stem } & \multicolumn{2}{|l|}{-0.245} & 0.112 & 66.1 & -2.192 & $0.032 *$ \\
\hline \multicolumn{2}{|c|}{ Phenological age (mature) } & \multicolumn{2}{|l|}{2.108} & 0.610 & 75.9 & 3.457 & $0.001 * * *$ \\
\hline \multicolumn{2}{|c|}{ Altitude (km a.s.1.) } & \multicolumn{2}{|l|}{-6.312} & 2.668 & 32.4 & -2.366 & $0.024 *$ \\
\hline \multicolumn{8}{|c|}{ Lichen species recorded only in the tree crown } \\
\hline Random factor & \multicolumn{2}{|l|}{ Variance } & SD & & $\mathrm{CHI} \mathrm{df}$ & $\mathrm{CHI}^{2}$ & $p$ \\
\hline Site & \multicolumn{2}{|l|}{6.691} & 2.587 & & \multirow[t]{2}{*}{1} & 7.058 & $0.008 * *$ \\
\hline Residual & 28.343 & & 5.324 & & & & \\
\hline \multicolumn{2}{|l|}{ Fixed factors } & \multicolumn{2}{|l|}{ Estimate } & SE & df & $t$ & $p$ \\
\hline \multicolumn{2}{|l|}{ Intercept } & 35.087 & & 2.781 & 58.1 & 12.618 & $0.000 * * *$ \\
\hline \multicolumn{2}{|c|}{ No. species on stem } & -0.522 & & 0.094 & 74.8 & -5.584 & $0.000 * * *$ \\
\hline \multicolumn{2}{|l|}{ DBH (m) } & -9.199 & & 2.450 & 75.6 & -3.754 & $0.000 * * *$ \\
\hline \multicolumn{2}{|c|}{ Phenological age (mature) } & 5.680 & & 1.862 & 74.2 & 3.051 & $0.003^{* *}$ \\
\hline
\end{tabular}

In contrast to the bryophytes, only 36 out of 227 lichen species were recorded only on stems (Fig. 7). One hundred fifty-one species were observed more often in crowns, and 62 species were significantly more frequent in crowns than on the stems. Twenty-nine out of 39 red-listed species were more frequent in crowns, and this difference was significant for the seven species Buellia erubescens, Hypogymnia vittata, Nephromopsis laureri, Ochrolechia pallescens, O. szatalaensis, Pachyphiale fagicola and Thelenella modesta.

\section{Discussion}

\section{Total number of species}

With a mean of 72 species ( 28 bryophytes +44 lichens) per tree the number of bryophytes and lichens was larger than expected. This large number was particularly astonishing since we optimized the sampling strategy only for bryophytes and not for lichens. Species numbers reported here for lichens are thus lower-bound estimates. Comparable studies of whole trees in similar climates are scarce. Boch et al. (2013a) surveyed beech, spruce and 


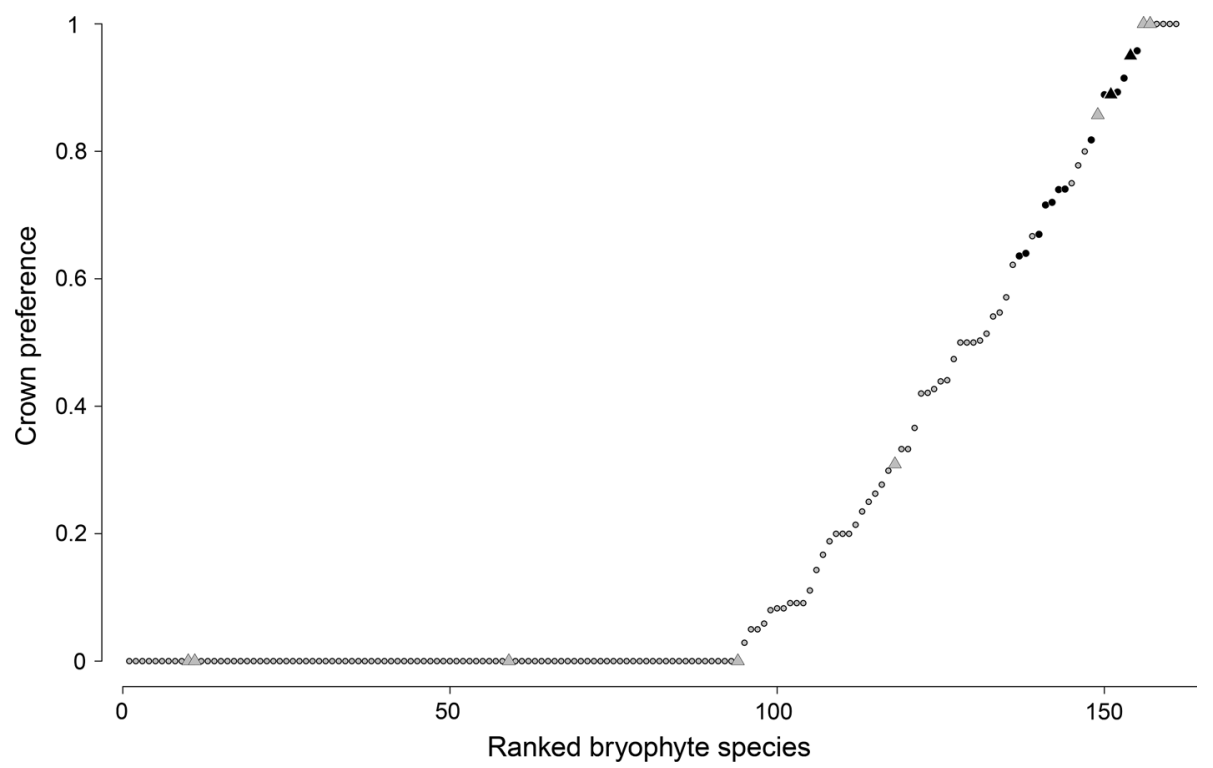

Fig. 6 Crown preference of bryophyte species on 80 sycamore maple trees. The crown preference was calculated as the number of trees where the species was recorded in the crown divided by the total number of trees where the species was found. Black symbols indicate species that were significantly $(p<0.05)$ more frequent in tree crowns. Triangles indicate species with Red List status CR, EN or VU and dots indicate species with status NT, LC or NE

pine trees in managed forests of temperate Europe. They similarly applied an extensive sampling design and found a mean of 6.0 bryophyte and 11.2 lichen species per tree. In other studies, more species were found per tree but the numbers still did not reach the lichen and bryophyte species richness reported here. For example, in a study of various tree species in a boreal forest in Wisconsin (United States), Hale (1952) found a maximum of 12 bryophyte (on elm and sugar maple) and 33 lichen (on red maple) species per tree. In a study conducted in an Estonian boreal forest, Marmor et al. (2013) found a mean of 41 and 34 lichen species on spruce and pine trees, respectively. Fritz (2009) studied European beech trees in a forest in southern Sweden and recorded between 14 and 55 species per tree, considering bryophytes and lichens together. In other climate zones, such as the tropics and subtropics, far more species per tree can be found (e.g. Sillett et al. 1995; Aptroot 1997; Romanski et al. 2011). The following factors most likely contributed to the high species numbers revealed by our study: (a) the sampling was extensive, with plots in all available microhabitats; (b) many of the trees we surveyed were old trees, which are known to be rich in epiphytic species (Vanderpoorten et al. 2004; Ranius et al. 2008; Fritz et al. 2009a); (c) the humid environment, which is known to promote the diversity of epiphytes (Heylen et al. 2005; Hylander et al. 2005) and which, in the case of bryophytes, allows many species that otherwise prefer different substrates (e.g. soil or rocks) to grow as epiphytes (Van Reenen and Gradstein 1983, pers. obs.); (d) in the study region the intensity of atmospheric pollutants, which caused a strong decline in epiphytic species richness in large parts of Europe, was never strong (e.g. Herzig and Urech 1991; ApSimon et al. 1994; Mylona 1996; Frahm 1998; van Herk 2001) and (e) light levels around solitary trees are higher than the ones around forest trees. The positive effect of light on epiphyte species 


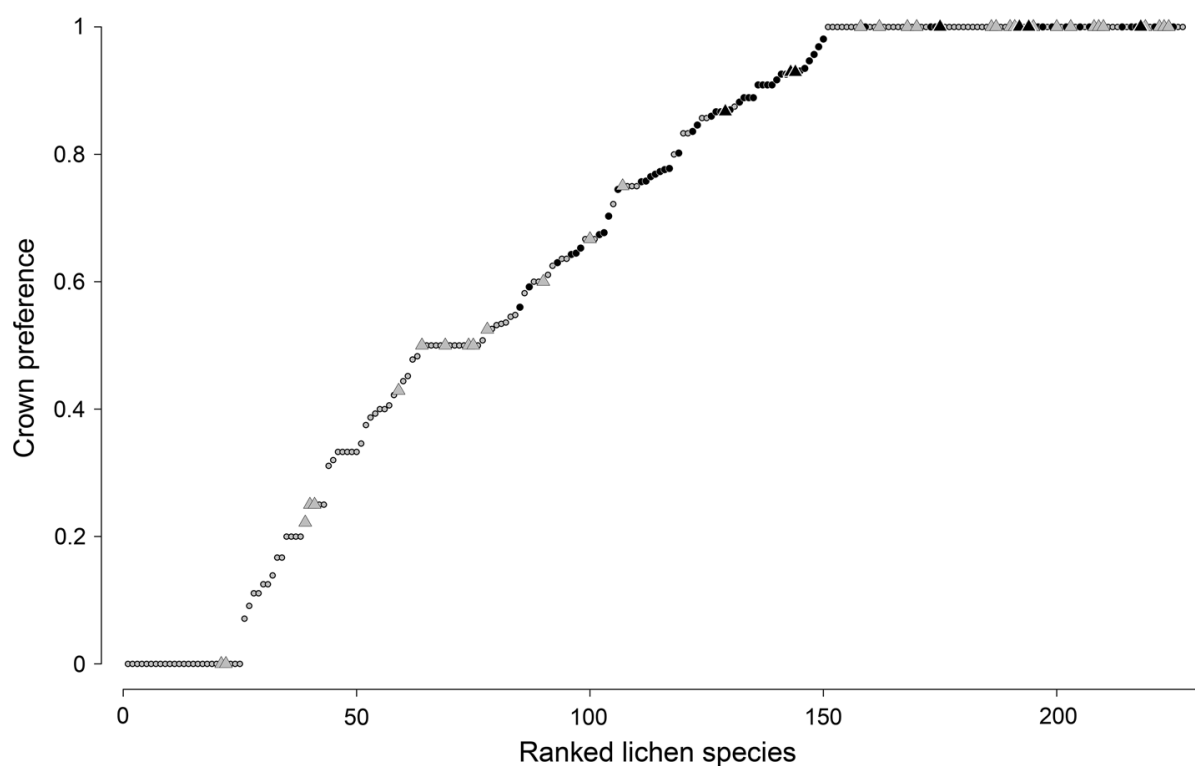

Fig. 7 Crown preference of lichen species on 80 sycamore maple trees. The crown preference was calculated as the number of trees where the species was recorded in the crown divided by the total number of trees where the species was found. Black symbols indicate species that were significantly $(p<0.05)$ more frequent in tree crowns. Triangles indicate species with Red List status CR, EN or VU and dots indicate species with status NT, LC or NE

richness has been reported in several studies (e.g. Barkman 1958; Löbel et al. 2006; Ellis 2012).

\section{Additional diversity in the crown}

At the tree level, a large proportion of species was recorded exclusively in the crown. This was especially true for lichens, for which more than $60 \%$ of the species were confined to the crown when considering a single tree. Similarly, Boch et al. (2013a) found that the proportion of species found exclusively in the crown was markedly higher for lichens than for bryophytes. Further, in a study of the vertical distribution of lichens on coniferous trees, Marmor et al. (2013) found that more than $60 \%$ of lichen species were confined to the tree crown. In contrast, in a study of eight crustose lichen species on oak trees in Sweden, Johansson et al. (2010) found that the detection probability was high when only the lowest $2 \mathrm{~m}$ were surveyed. However, the species that they considered (e.g. Calicium viride) typically prefer the fissured bark of old trees and are thus more likely to be adequately sampled on the lower parts of tree stems.

When only epiphytes were considered in our study, the proportion of bryophyte species recorded only in crowns was markedly higher compared to the total species numbers $(29.1$ vs. $41.7 \%$ ). This increase is linked to the fact that, on average, almost half of the bryophyte species on a tree were non-epiphytes recorded mainly at the tree base (e.g. ground dwelling species such as Plagiomnium rostratum and Thuidium assimile). These species thus masked the vertical distribution pattern of the epiphytes. Similarly, Fritz (2009) 
reported that ground dwelling bryophyte species contributed substantially to the diversity at tree heights of $0-2 \mathrm{~m}$.

Increasing the number of sampled trees rapidly reduced the proportion of bryophyte species recorded only in the crowns. In contrast, more than $30 \%$ of the lichen species were found exclusively in the crowns when all 80 trees were considered together, and the accumulation curve of these exclusive crown species continued to ascend. These results are in agreement with those of Boch et al. (2013a), who found very similar numbers. The main reason for these findings is the general distribution pattern of bryophytes and lichens on trees. Usually, bryophytes are more abundant in the lower parts whereas lichens are more abundant in the upper parts of trees (e.g. Jarman and Kantvilas 1995; McCune et al. 1997; Milne and Louwhoff 1999; Hilmo et al. 2013). Lichens are generally better adapted to the rather extreme climate of the outer crown (high light levels and thus higher temperatures and correspondingly faster drying). Most epiphytic lichens are light-demanding species, and their desiccation tolerance and poikilohydric strategy enable them to cope with the very dry conditions that occur frequently in the outer crown (Barkman 1958; Kranner et al. 2008).

For bryophytes the different sampling strategies applied on the stem (predefined plots) and in the crown (mostly selective plots) might have biased our results towards crown habitats. However, we are confident that this bias is very small because we observed that in most cases all species present on the stem were included in the two stem plots. Moreover, due to the restricted accessibility of some parts of the crown, single bryophyte species might also have been missed there, e.g. on thin branches of the outer crown.

\section{Relationship between additional diversity in the crown and diversity on the stem}

A negative relationship between the number of additional crown species and the number of species on the stem was found for bryophytes and for lichens. The additional diversity in the crown was also influenced by tree parameters and environmental variables. The negative relationship between the number of species on the stem and the additional crown species may be explained by species that usually occur in the crowns but can also exist on the stem if conditions are suitable there. The occurrence of these species on the stem may be driven by environmental conditions and microhabitat availability on the stem. For example, Barkman (1958) reported vertical shifts in epiphyte vegetation zones and in the presence of single species that were caused by altered environmental conditions. The negative relationship detected between DBH and the number of additional lichen species may be caused by a species-area relationship. Generally, the available bark area on the stem is by far smaller than the bark area in the crown (Sillett and Antoine 2004), which may limit the number of generalist species (=species able to grow on the stems and in the crowns) on the stem. If there is more area available on the stem, more generalist species may be found there. In contrast, Boch et al. (2013a) found a positive relationship between DBH and the number of additional crown species. However, they studied forest trees where species diversity on the stem may be limited by low light levels (Barkman 1958; Löbel et al. 2006; Ellis 2012). Moreover, the relations between environmental variables, number of stem species and the additional crown species might differ among regions and tree species. At the moment, it seems difficult to compare the results of different diversity assessments and to generalize the results. Clearly, more studies including different forest types and tree species are needed. 
However, our findings indicate that the diversity detected on the stem does not necessarily reflect the total diversity on the tree. Consequently, diversity assessments performed only on stems cannot be transferred to the tree level, even when many stems of a site are investigated. Similarly, in a study conducted on Norway spruce in Estonia, the diversity of lichens on the lower $2 \mathrm{~m}$ was not significantly correlated with the total diversity of the trees (Marmor et al. 2013). In contrast, the same study revealed a strong positive relationship between the diversity of lichens in the lower $2 \mathrm{~m}$ and the total diversity on pine trees, but this may be partly due to the non-independence of the two variables and should be interpreted with caution.

\section{Crown preference and red-listed species}

Most lichen species on the trees studied here were epiphytes and were more frequent in the crowns than on the stems. In contrast, most bryophyte species were non-epiphytes and recorded predominantly on the stems. The much higher specialization of lichens to tree crowns than of bryophytes is a well-known phenomenon (e.g. Hale 1965; McCune et al. 1997; Milne and Louwhoff 1999; Coote et al. 2008; Fritz 2009) explained by the vertical changes in microclimate and the differing ecological requirements of bryophytes and lichens (Barkman 1958; Coote et al. 2008; Fritz 2009). The tree base is strongly influenced by the environmental conditions of the soil (generally high humidity) and is usually dominated by bryophyte species (Barkman 1958), whereas lichens are more capable of coping with the low and more variable humidity in the crown (Barkman 1958; Pearson 1969). However, the occurrence of lichen species on stems is strongly influenced by tree age: a large number of lichen species (e.g. Buellia erubescens, Lecanora pulicaris) are early colonizers of stems of young trees. With an increasing stem diameter and a continuous change in bark structure and chemistry, this initial lichen community gradually moves upwards on the stem and colonizes branches and twigs. With increasing tree age, more and more bryophytes settle on the stem and on thick branches (Barkman 1958; Sillett and Antoine 2004; pers. obs.). The rough and cracked bark on older parts of a tree has a higher water capacity and favours the establishment of a high bryophyte coverage (Barkman 1958; Fritz et al. 2009b; Fritz 2009).

Many red-listed lichen species were recorded only in the crowns. This finding highlights the importance of the crown as lichen habitat and has implications for biodiversity surveys and Red List assessments. It seems possible that at least some crown specialists are considered to be rare because of the biased sampling method that is normally used. If tree crowns are not sampled, it seems likely that frequency estimates of a number of species are biased, which could lead to an underestimation of the number of individuals and eventually to an overestimation of extinction risks. However, it is likely that species considered crown specialists on the trees examined in our study also occur on stems of sycamore maple trees with thinner stems, on other tree species or on the twigs of shrubs. For example, the lichens Ochrolechia pallescens (EN) and Menegazzia terebrata (VU), which were more frequent in crowns in our study, are usually found on stems where they prefer smooth or only slightly rough bark (Wirth et al. 2013). On the other hand, the special ecology of the tree crown makes it a distinct habitat that is essential for specialist species (Barkman 1958). Furthermore, the longer time interval available for arrival and establishment might favour the occurrence of rare species in tree crowns of old trees. The lichen Lobaria amplissima (EN), for example, is known to grow mainly in the crowns of old trees (Wirth et al. 2013). In addition, the beard lichens Usnea florida (EN), U. glabrescens (VU) and U. intermedia (VU) are typical crown species (Wirth et al. 2013). Also several other studies found a 
positive relation between tree- or stand-age and the occurrence of red-listed species as well as overall species richness of epiphytic bryophytes and lichens (Peterson and McCune 2001; Fritz et al. 2008; Fritz 2009; Jairus et al. 2009; Nascimbene et al. 2010; Marmor et al. 2011; Boch et al. 2013a, b). E.g. Fritz (2009) studied the vertical distribution of bryophytes and lichens on 16 fallen beech trees and found red-listed lichen species almost exclusively on old trees, with more than half of them exclusively above $2 \mathrm{~m}$.

In general, tree crowns seem to be less important for bryophytes than for lichens because most of the bryophyte species were also found on the stems when all 80 trees were considered. Nevertheless, some species were far more frequent in the crowns, such as the moss Tayloria rudolphiana (VU), which preferably grows on large branches in the crown of old sycamore maple trees in areas with high air humidity (Grims 1999; Weddeling et al. 2005; Hofmann et al. 2006) and light demanding pioneers like Orthotrichum rogeri (VU). This latter species has relatively high light requirements but also needs some shelter (Lüth 2010). This combination of conditions can be found in the upper part of tree crowns, where this species has frequently been found in recent years (this study, pers. obs., Lüth 2010). Both $T$. rudolphiana and $O$. rogeri are listed in the habitats directive of the European Union (FFH, appendix II) as species of conservation concern (Council of the European Commission 1992), highlighting the high nature conservation value of the studied trees and the importance of considering tree crowns in addition to stems.

\section{Conclusions}

Our findings underline the need to include tree crowns in diversity assessments of bryophytes and lichens. For bryophytes, sampling several stems can give a good estimation of the species present at a particular site. However, frequency estimates may be highly biased for lichens and bryophytes if the crowns are not considered in diversity assessments. Crowns represent key habitats, particularly for light demanding pioneers and for highly specialized, often rare and threatened epiphytes. For such species, tree crowns comprise the major part of the potentially colonizable surface area and should be considered more intensively in future revisions of Red Lists. Moreover, the study emphasizes the high conservation value of old trees for cryptogam diversity.

Acknowledgments Major thanks are given to the Bristol Foundation, chaired by Mario Broggi, for providing major funding for this project. Furthermore, we acknowledge the Federal Office for the Environment (FOEN) and the Nature Park Diemtigtal for financial support. Sincere thanks are given to L. Hedenäs, H. Köckinger, N. Schnyder, C. Schubiger and E. Urmi for the revision of ambiguous bryophyte specimens, to H. Hofmann and C. Schröck for providing information about Tayloria rudolphiana, to J. Ecker and J. Betsch for their help in the field, to A. Bedolla, K. Ecker, H. and M. Küchler, M. Meier and S. Stofer for their help with databases, GIS, Vegedaz and French language translations, to H. Sonntag at Nature Park Karwendel, to L. Waser for the calculation of CIR images, and to the Tiris-services of the Tyrol province and the Sagisservices of the Salzburg province for the provision of Geo data.

\section{Compliance with ethical standards}

Conflict of interest The authors declare that they have no conflict of interest. 


\section{References}

ApSimon HM, Warren RF, Wilson JJN (1994) The abatement strategies assessment model-ASAM: Applications to reductions of sulphur dioxide emissions across Europe. Atmos Environ 28:649-663. doi:10.1016/1352-2310(94)90042-6

Aptroot A (1997) Lichen biodiversity in Papua New Guinea, with report of 173 species on one tree. Bibl Lichenol 68:203-213

Barker M, Pinard M (2001) Forest canopy research: sampling problems, and some solutions. In: Linsenmair KE, Davis AJ, Fiala B, Speight MR (eds) Tropical Forest Canopies: ecology and management. Springer, New York, pp 23-38

Barkman JJ (1958) Phytosociology and ecology of cryptogamic epiphytes, including a taxonomic survey and description of their vegetation units in Europe. Van Gorcum \& Comp, Assen

Bates D, Maechler M, Bolker B, Walker S (2015) lme4: linear mixed-effects models using Eigen and S4. R package version 1.1-8. http://cran.r-project.org/package=lme4. Accessed June 2015

Baumgartner A, Reichel E, Weber G (1983) Der Wasserhaushalt der Alpen. Oldenbourg, Munich

Boch S, Müller J, Prati D, Blaser S, Fischer M (2013a) Up in the tree-the overlooked richness of bryophytes and lichens in tree crowns. PLoS One. doi:10.1371/journal.pone.0084913

Boch S, Prati D, Hessenmöller D, Schulze ED, Fischer M (2013b) Richness of lichen species, especially of threatened ones, is promoted by management methods furthering stand continuity. PLoS One. doi:10. 1371/journal.pone.0055461

Boudreault C, Gauthier S, Bergeron Y (2000) Epiphytic lichens and bryophytes on Populus tremuloides along a chronosequence in the southwestern boreal forest of Quebec, Canada. Bryologist 103:725-738

Buckley HL (2011) Isolation affects tree-scale epiphytic lichen community structure on New Zealand mountain beech trees. J Veg Sci 22:1062-1071. doi:10.1111/j.1654-1103.2011.01315.x

Caruso A, Öckinger E, Winqvist C, Ahnström J (2015) Different patterns in species richness and community composition between trees, plants and epiphytic lichens in semi-natural pastures under agri-environment schemes. Biodivers Conserv 24:1729-1742. doi:10.1007/s10531-015-0892-x

Clauzade G, Roux C, Houmeau JM, Raimbault P (1985) Likenoj de Okcidenta Europo: ilustrita determinlibro. Bull Soc Bot Centre-Ouest, nouv sér, num spéc 7:1-893

Clerc P, Truong C (2012) Catalogue des lichens de Suisse. http://www.ville-ge.ch/musinfo/bd/cjb/ cataloguelichen [Version 2.0, 11.06.2012]. Accessed 12 Aug 2015

Coote L, Smith GF, Kelly DL, O’Donoghue S, Dowding P, Iremonger S, Mitchell FJG (2008) Epiphytes of sitka spruce (Picea sitchensis) plantations in Ireland and the effects of open spaces. Biodivers Conserv 17:953-968. doi:10.1007/s10531-007-9302-3

Council of the European Commission (1992) Council directive 92/43/EEC of 21 May 1992 on the conservation of natural habitats and of wild fauna and flora. Off J Eur Communities Ser L 206:7-49

Dittrich S, Hauck M, Schweigatz D, Dörfler I, Hühne R, Bade C, Jacob M, Leuschner C (2013) Separating forest continuity from tree age effects on plant diversity in the ground and epiphyte vegetation of a Central European mountain spruce forest. Flora 208:238-246

Ellis CJ (2012) Lichen epiphyte diversity: a species, community and trait-based review. Perspect Plant Ecol Evol Syst 14:131-152. doi:10.1016/j.ppees.2011.10.001

Frahm JP (1998) Moose als Bioindikatoren. Quelle \& Meyer, Wiesbaden

Frahm JP, Frey W (1992) Moosflora, 3rd edn. Ulmer, Stuttgart

Friedel A, Oheimb GV, Dengler J, Härdtle W (2006) Species diversity and species composition of epiphytic bryophytes and lichens-a comparison of managed and unmanaged beech forests in NE Germany. Feddes Repert 117:172-185. doi:10.1002/fedr.200511084

Fritz Ö (2009) Vertical distribution of epiphytic bryophytes and lichens emphasizes the importance of old beeches in conservation. Biodivers Conserv 18:289-304. doi:10.1007/s10531-008-9483-4

Fritz Ö, Gustafsson L, Larsson K (2008) Does forest continuity matter in conservation?-A study of epiphytic lichens and bryophytes in beech forests of southern Sweden. Biol Conserv 141:655-668. doi:10.1016/j.biocon.2007.12.006

Fritz Ö, Niklasson M, Churski M (2009a) Tree age is a key factor for the conservation of epiphytic lichens and bryophytes in beech forests. Appl Veg Sci 12:93-106. doi:10.1111/j.1654-109X.2009.01007.x

Fritz Ö, Brunet J, Caldiz M (2009b) Interacting effects of tree characteristics on the occurrence of rare epiphytes in a Swedish beech forest area. Bryologist 112:488-505. doi:10.1639/0007-2745-112.3.488

Grims F (1999) Die Laubmoose Österreichs, Catalogus Florae Austriae II, Bryophyten (Moose) 1, Musci (Laubmoose). Österreichische Akademie der Wissenschaften, Vienna

Hale ME (1952) Vertical distribution of cryptogams in a virgin forest in Wisconsin. Ecology 33:398-406

Hale ME (1965) Vertical distribution of cryptogams in a red maple swamp in Connecticut. Bryologist 68:193-197. doi:10.2307/3241012 
Herzig R, Urech M (1991) Flechten als Bioindikatoren. Bibl Lichenol 43:1-283

Heylen O, Hermy M, Schrevens E (2005) Determinants of cryptogamic epiphyte diversity in a river valley (Flanders). Biol Conserv 126:371-382. doi:10.1016/j.biocon.2005.06.014

Hijmans RJ, Cameron SE, Parra JL, Jones PG, Jarvis A (2005) Very high resolution interpolated climate surfaces for global land areas. Int J Climatol 25:1965-1978. doi:10.1002/joc.1276

Hill MO, Bell N, Bruggeman-Nannenga M, Brugues M, Cano MJ, Enroth J, Flatberg KI, Frahm JP, Gallego MT, Garilleti R, Guerra J, Hedenas L, Holyoak DT, Ignatov MS, Lara F, Mazimpaka V, Munoz J, Söderström L (2006) An annotated checklist of the mosses of Europe and Macaronesia. J Bryol 28:198-267. doi:10.1179/174328206X119998

Hilmo O, Gauslaa Y, Rocha L, Lindmo S, Holien H (2013) Vertical gradients in population characteristics of canopy lichens in boreal rainforests of Norway. Botany 91:814-821. doi:10.1139/cjb-2013-0105

Hofmann H, Müller N, Schnyder N (2006) Merkblätter Artenschutz-Moose. Durch die Natur- und Heimatschutzverordnung schweizweit geschützte Moose (NHV, Anhang 2). http://www.nism.uzh.ch/ Naturschutz/Artenschutz_Moose_D.pdf. Accessed 30 July 2015

Hylander K, Dynesius M, Jonsson BG, Nilsson C (2005) Substrate form determines the fate of bryophytes in riparian buffer strips. Ecol Appl 15:674-688. doi:10.1890/04-0570

Ignatova EA, Ignatov MS (2011) The genus Thamnobryum (Neckeraceae, Bryophyta) in Russia. Arctoa 20:137-151

IUCN (2001) IUCN red list categories and criteria version 3.1. Gland, Cambridge

Jairus K, Lõhmus A, Lõhmus P (2009) Lichen acclimatization on retention trees: a conservation physiology lesson. J Appl Ecol 46:930-936. doi:10.1111/j.1365-2664.2009.01672.x

Jarman SJ, Kantvilas G (1995) Epiphytes on an old huon pine tree (Lagarostrobos franklinii) in Tasmanian rainforest. New Zeal J Bot 33:65-78. doi:10.1080/0028825X.1995.10412944

Johansson V, Snäll T, Johansson P, Ranius T (2010) Detection probability and abundance estimation of epiphytic lichens based on height-limited surveys. J Veg Sci 21:332-341. doi:10.1111/j.1654-1103. 2009.01146.x

Johansson V, Ranius T, Snäll T (2012) Epiphyte metapopulation dynamics are explained by species traits, connectivity, and patch dynamics. Ecology 93:235-241. doi:10.1890/11-0760.1

Jüriado I, Liira J, Paal J, Suija A (2009) Tree and stand level variables influencing diversity of lichens on temperate broad-leaved trees in boreo-nemoral floodplain forests. Biodivers Conserv 18:105-125. doi:10.1007/s10531-008-9460-y

Kenkel NC, Bradfield GE (1986) Epiphytic vegetation on Acer macrophyllum: a multivariate study of species-habitat relationships. Vegetatio 68:43-53. doi:10.1007/BF00031579

Kranner I, Beckett R, Hochman A, Nash TH (2008) Desiccation-tolerance in lichens: a review. Bryologist 111:576-593. doi:10.1639/0007-2745-111.4.576

Kumar L, Skidmore AK, Knowles E (1997) Modelling topographic variation in solar radiation in a GIS environment. Int J Geogr Inf Sci 11:475-497. doi:10.1080/136588197242266

Kuznetsova A, Brockhoff PB, Christensen RHB (2015) LmerTest: Tests for random and fixed effects for linear mixed effect models. R package, version 2.0-29. http://cran.r-project.org/package=lmerTest. Accessed June 2015

Lie MH, Arup U, Grytnes JA, Ohlson M (2009) The importance of host tree age, size and growth rate as determinants of epiphytic lichen diversity in boreal spruce forests. Biodivers Conserv 18:3579-3596. doi:10.1007/s10531-009-9661-Z

Löbel S, Snäll T, Rydin H (2006) Species richness patterns and metapopulation processes-evidence from epiphyte communities in boreo-nemoral forests. Ecography 29:169-182. doi:10.1111/j.2006.09067590.04348.x

Löbel S, Snäll T, Rydin H (2009) Mating system, reproduction mode and diaspore size affect metacommunity diversity. J Ecol 97:176-185. doi:10.1111/j.1365-2745.2008.01459.x

Lõhmus P, Rosenvald R, Lõhmus A (2006) Effectiveness of solitary retention trees for conserving epiphytes: differential short-term responses of bryophytes and lichens. Can J For Res 36:1319-1330. doi:10.1139/x06-032

Lüth M (2010) Ökologie und Vergesellschaftung von Orthotrichum rogeri. Herzogia 23:121-149

Marmor L, Tõrra T, Saag L, Randlane T (2011) Effects of forest continuity and tree age on epiphytic lichen biota in coniferous forests in Estonia. Ecol Indic 11:1270-1276. doi:10.1016/j.ecolind.2011.01.009

Marmor L, Tõrra T, Saag L, Leppik E, Randlane T (2013) Lichens on Picea abies and Pinus sylvestrisfrom tree bottom to the top. Lichenol 45:51-63. doi:10.1017/S0024282912000564

McCune B, Amsberry KA, Camacho FJ, Clery S, Cole C, Emerson C, Felder G, French P, Greene D, Harris R, Hutten M, Larson B, Lesko M, Majors S, Markwell T, Parker GG, Pendergrass K, Peterson EB, Peterson ET, Platt J, Proctor J, Rambo T, Rosso A, Shaw D, Turner R, Widmer M (1997) Vertical profile of epiphytes in a Pacific Northwest old-growth forest. Northwest Sci 71:145-152 
Milne J, Louwhoff S (1999) Vertical distribution of bryophytes and lichens on a myrtle beech, Nothofagus cunninghamii (Hook.) Oerst. Hikobia 13:23-30

Mylona S (1996) Sulphur dioxide emissions in Europe 1800-1991 and their effect on sulphur concentrations and depositions. Tellus 48:662-689. doi:10.1034/j.1600-0889.1996.t01-2-00005.x

Nascimbene J, Marini L, Nimis PL (2010) Epiphytic lichen diversity in old-growth and managed Picea abies stands in Alpine spruce forests. For Ecol Manag 260:603-609. doi:10.1016/j.foreco.2010.05.016

Nebel M, Philippi G (2000) Die Moose Baden-Württembergs. Bd 1. Ulmer, Stuttgart

Nebel M, Philippi G (2001) Die Moose Baden-Württembergs. Bd 2. Ulmer, Stuttgart

Nebel M, Philippi G (2005) Die Moose Baden-Württembergs. Bd 3. Ulmer, Stuttgart

Paltto H, Nordberg A, Nordén B, Snäll T (2011) Development of secondary woodland in oak wood pastures reduces the richness of rare epiphytic lichens. PLoS One 6:1-8. doi:10.1371/journal.pone.0024675

Pearson LC (1969) Influence of temperature and humidity on distribution of lichens in a Minnesota bog. Ecology 50:740-746

Peterson EB, McCune B (2001) Diversity and succession of epiphytic macrolichen communities in lowelevation managed conifer forests in Western Oregon. J Veg Sci 12:511-524. doi:10.2307/3237003

Ranius T, Johansson P, Berg N, Niklasson M (2008) The influence of tree age and microhabitat quality on the occurrence of crustose lichens associated with old oaks. J Veg Sci 19:653-662. doi:10.3170/20088-18433

Rasmussen L (1975) The bryophytic epiphyte vegetation in the forest, Slotved Skov, northern Jutland. Linbergia 3:15-38

Romanski J, Pharo EJ, Kirkpatrick JB (2011) Epiphytic bryophytes and habitat variation in montane rainforest, Peru. Bryologist 114:720-731. doi:10.1639/0007-2745-114.4.720

Rose F (1991) The importance of old trees, including pollards, for lichen and bryophyte epiphytes. In: Read HJ (ed) Pollard and veteran tree management. Corporation of London, London, pp 28-29

Saag L, Saag A, Randlane T (2009) World survey of the genus Lepraria (Stereocaulaceae, lichenized Ascomycota). Lichenologist 41:25-60

Scheidegger C, Groner U, Keller C, Stofer S (2002a) Monitoring with lichens-monitoring lichens. In: Nimis PL, Scheidegger C, Wolseley PA (eds) Monitoring with lichens-monitoring lichens. Springer, New York, pp 359-365

Scheidegger C, Clerc P, Dietrich M, Frei M, Groner U, Keller C, Roth I, Stofer S, Vust M (2002b) Rote Liste der gefährdeten baum- und erdbewohnenden Flechten der Schweiz. WSL, CJB, BUWAL, Bern

Schnyder N, Bergamini A, Hofmann H, Müller N, Schubiger-Bossard C, Urmi E (2004) Rote Liste der gefährdeten Moose der Schweiz. Vollzug Umwelt. BUWAL, FUB \& NISM, BUWAL-Reihe

Sillett SC, Antoine ME (2004) Lichens and bryophytes in forest canopies. In: Lowman MD, Rinker HB (eds) Forest Canopies, 2nd edn. Elseiver Academic Press, New York, pp 151-174

Sillett SC, Gradstein SR, Griffin D (1995) Bryophyte diversity of Ficus tree crowns from cloud forest and pasture in Costa Rica. Bryol 98:251-260

Söderström L, Urmi E, Váňa J (2002) Distribution of Hepaticae and Anthocerotae in Europe and Macaronesia. Lindbergia 27:3-47

Söderström L, Urmi E, Ván̆a J (2007) The distribution of Hepaticae and Anthocerotae in Europe and Macaronesia-update 1-427. Cryptogam Bryol 28:299-350

Stewart KJ, Mallik AU (2006) Bryophyte responses to microclimatic edge effects across riparian buffers. Ecol Appl 16:1474-1486. doi:10.1890/1051-0761

R Core Team (2015) R: a language and environment for statistical computing. http://www.r-project.org/. Accessed June 2015

Van Herk CM (2001) Bark pH and susceptibility to toxic air pollutants as independent causes of changes in epiphytic lichen composition in space and time. Lichenologist 33:419-441. doi:10.1006/lich.2001. 0337

Van Reenen GBA, Gradstein SR (1983) Studies on Colombian cryptogams XX. Acta Bot Neerl 32:163-175

Vanderpoorten A, Engels P, Sotiaux A (2004) Trends in diversity and abundance of obligate epiphytic bryophytes in a highly managed landscape. Ecography 27:567-576. doi:10.1111/j.0906-7590.2004. 03890.x

Weddeling K, Ludwig G, Hachtel M (2005) Die Moose (Bryophyta, Marchantiophyta, Anthocerophyta) der FHH-Richtlinie. In: Petersen B, Ellwanger G, Biewald G et al (eds) Das europäische Schutzgebietssystem Natura 2000. Ökologie und Verbreitung von Arten der FFH-Richtlinie in Deutschland. Landwirtschaftsverlag, Münster, pp 207-329

Whitelaw M, Burton MAS (2015) Diversity and distribution of epiphytic bryophytes on Bramley's Seedling trees in East of England apple orchards. Glob Ecol Conserv 4:380-387. doi:10.1016/j.gecco.2015.07. 014

Wirth V (1987) Die Flechten Baden-Württembergs. Ulmer, Stuttgart 
Wirth V, Hauck M, Schultz M, De Bruyn U (2013) Die Flechten Deutschlands. Ulmer, Stuttgart

Yang K, Koike T (2002) Estimating surface solar radiation from upper-air humidity. Sol Energy 72:177-186. doi:10.1016/S0038-092X(01)00084-6

Yarranton GA (1972) Distribution and succession of epiphytic lichens on black spruce near Cochrane, Ontario. Bryologist 75:462-480

Zimmermann NE, Roberts DW (2001) Final report of the MLP climate and biophysical mapping project. https://www.wsl.ch/staff/niklaus.zimmermann/mlp/mlp_report.pdf. Accessed 12 June 2015 